\title{
The production of and sensitivity to cues that delay puberty and prolong subsequent oestrous cycles in female mice are influenced by prior intrauterine position
}

\author{
F. S. vom Saal \\ Division of Biological Sciences, and John M. Dalton Research Center, University of Missouri, \\ Columbia, Missouri 65211, USA
}

\begin{abstract}
Summary. Four experiments were conducted with CF-1 house mice (Mus domesticus) to examine the relationship between a female's prior intrauterine position $(2 \mathrm{M}=$ between 2 male fetuses, $1 \mathrm{M}=$ next to one male fetus, $0 \mathrm{M}=$ not next to a male fetus) and the timing of puberty and length of subsequent oestrous cycles under a variety of housing conditions. The results of Exp. 1 confirmed that the presence of males was required for females to enter puberty and exhibit regular oestrous cycles, regardless of prior intrauterine position. When housed individually after weaning either with a male in the cage or separated by a wire mesh partition, 0M-females ovulated and mated at a younger age and had shorter post-pubertal oestrous cycles than did 2M-females (1M-females were intermediate between $0 \mathrm{M}$ - and $2 \mathrm{M}$-females). Other females were also housed after weaning with a male or separated by a wire mesh partition from a male in a variety of social environments (4 0M-females and $12 \mathrm{M}$-female, $42 \mathrm{M}$-females and $10 \mathrm{M}$-female, $51 \mathrm{M}$-females, $30 \mathrm{M}$-females and 3 $2 \mathrm{M}$-females). The objective of these different housing conditions was to determine whether prior intrauterine position influenced the transmission of and/or sensitivity to cues that delay puberty and prolong subsequent oestrous cycles. Relative to $2 \mathrm{M}$-females, $0 \mathrm{M}$-females both produced more potent cues and were more sensitive to the cues (again, $1 \mathrm{M}$-females were intermediate between $0 \mathrm{M}$ - and $2 \mathrm{M}$-females). Specifically, in the presence of other females, puberty was delayed and post-pubertal oestrous cycles were prolonged to the greatest extent in $0 \mathrm{M}$-females. Prior intrauterine position is therefore a source of individual variation in the production of and sensitivity to cues that modulate the timing of puberty and the length of subsequent oestrous cycles in female mice. The findings suggest that prenatally-androgenized $2 \mathrm{M}$-females may have a reproductive advantage over other females at high population densities.
\end{abstract}

Keywords: pheromones; puberty; oestrous cycle; intrauterine position; sexual differentiation; mouse

\section{Introduction}

The regulation of the timing of the first ovulation signalling puberty and the characteristics of subsequent oestrous cycles in female house mice are complicated due to the marked effects on these processes of pheromonal cues produced by both males and females (Bronson \& Macmillan, 1983; Vandenbergh, 1983; Drickamer, 1986). Pheromonal cues emitted by males and other females act to regulate the timing of puberty and the length of subsequent oestrous cycles by modulating gonadotrophin secretion (Bronson \& Desjardins, 1974; Bronson \& Coquelin, 1980; Ryan \& Schwartz, 1980; Bronson \& Macmillan, 1983). The regulation of puberty in female mice by cues produced by both sexes has been proposed to play an important role in controlling population size (Bronson, 1979; Massey \& Vandenbergh, 1980; vom Saal, 1984; Vandenbergh \& Coppola, 1986). 
Three main facts concerning the timing of puberty and subsequent ovulatory cycles in house mice are now established: (1) in juvenile females, both pheromonal and tactile cues produced by adult males advance the age at puberty and shorten subsequent oestrous cycles (Vandenbergh, 1973; Drickamer, 1974; Bronson \& Maruniak, 1975); (2) pheromonal cues produced by females (juvenile and adult) can (a) delay the pubertal ovulation in juvenile females and (b) lengthen subsequent cycles (Vandenbergh et al., 1972; Drickamer, 1977; McIntosh \& Drickamer, 1977); and (3) the dominance relationship of a female's sensitivity to cues produced by males and other females changes during adolescence. For example, during early adolescence, being housed with other females (5-6/standard mouse cage) completely overrides the accelerating action of a male. Urine from grouped females also overrides the accelerating effect of male urine (Drickamer, 1982). In contrast, in some circumstances cues produced by males can override the inhibitory effect of grouping in adult females (Vandenbergh, 1973; vom Saal et al., 1981; Bronson \& Macmillan, 1983; Drickamer, 1982).

During the last third of pregnancy, when prenatal sexual differentiation occurs, female mouse fetuses differ in the concentrations of testosterone and oestradiol that they are exposed to based on their intrauterine position next to fetuses of the same or opposite sex. Females located between 2 male fetuses in utero ( $2 \mathrm{M}$ females) have significantly higher amniotic fluid and blood concentrations of testosterone but lower blood concentrations of oestradiol than do females located between 2 female fetuses (0M females; vom Saal \& Bronson, 1980a; F. S. vom Saal, unpublished observation). Female fetuses located between a male and a female fetus (1M females) are intermediate between $0 \mathrm{M}$ - and $2 \mathrm{M}$-females in their testosterone and oestradiol concentrations (F. S. vom Saal, unpublished observation). These $0 \mathrm{M}, 1 \mathrm{M}$ and $2 \mathrm{M}$ female mice (as well as male mice from different intrauterine positions; vom Saal et al., 1983) differ in a broad range of morphological, physiological and behavioural characteristics. This phenomenon also occurs in rats, gerbils and pigs (vom Saal, 1981, 1983, 1989; Rohde-Parfet et al., 1988; Clark \& Galef, 1988).

Alterations of sex hormone concentrations during perinatal (prenatal and neonatal) life lead to changes in reproductive function that become apparent during the pubertal period in female rodents (Gorski, 1979; vom Saal, 1981; vom Saal \& Finch, 1988). The objective of the present set of experiments was to examine the relationship between a female mouse's prior intrauterine position (and thus the concentrations of gonadal steroids to which she was exposed in utero) and the timing of puberty and length of subsequent oestrous cycles under a variety of housing conditions. Of particular interest was determining whether prior intrauterine position influenced the transmission of and/or sensitivity to cues that regulate the timing of puberty and the length of subsequent oestrous cycles in female mice.

\section{General Methods}

Experimental animals. To produce animals from known intrauterine positions, adult, virgin female mice were timemated by being paired with a male for $4 \mathrm{~h}$ beginning at 08:00 h. Insemination was verified by the presence of a copulatory plug. CF-1 mice litter 20 days after insemination (Day $1=$ day of insemination). Beginning at $08: 00 \mathrm{~h}$ on Day 20, females were killed by cervical dislocation, and the fetuses were rapidly removed from the uterine horns. Fetal sex was determined by the length of the anogenital space, and animals were sorted based on their intrauterine positions $(2 \mathrm{M}=$ between 2 male fetuses, $1 \mathrm{M}=$ next to one male fetus, $(0 \mathrm{M}=$ not next to a male fetus; Fig. 1$)$.

Amniotic fluid was aspirated from the respiratory tract of the young immediately after removal from the amniotic sac. All young were kept under heat lamps until they were fully active, at which time they were fostered to mothers that had delivered naturally within the preceding $24 \mathrm{~h}$. These mothers were removed from their cages, their own young were removed, killed and replaced with the young from known intrauterine positions, and the mother was then returned to the home cage. Infant mortality with this procedure has averaged $7 \%$ over many years of delivering and fostering fetuses. Foster litters consisted of 10 young, with $51 \mathrm{M}$-females being placed with either $50 \mathrm{M}$ - or $52 \mathrm{M}$ females (litter size in CF-1 mice is 12). Females were thus raised without male sibs. The presence of males in litters influences the timing of puberty in female mice (Drickamer, 1976).

Assignment of animals to experiments. At weaning on Day 23 after birth, the foster mother was removed from the cage. The experimental females were weighed on both Day 24 and 25 . To be included in an experimental group a female had to weigh between 13.0 and $15.5 \mathrm{~g}$ at 25 days of age, since body weight as well as age influences whether 


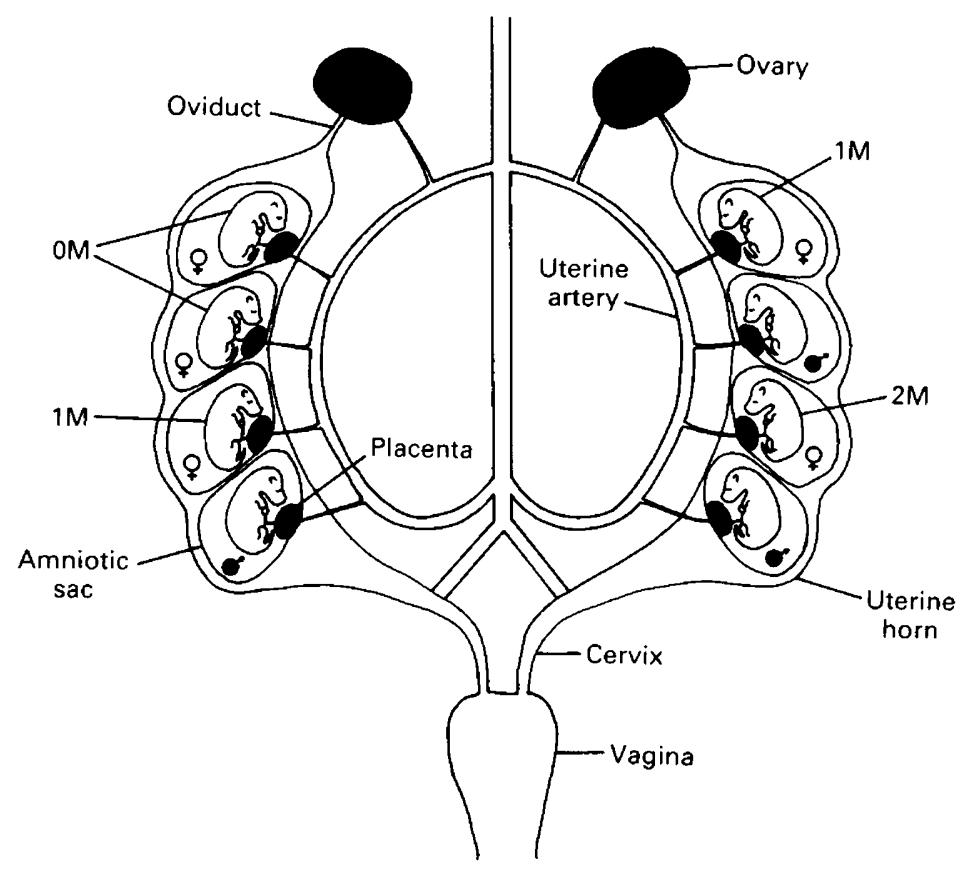

Fig. 1. Schematic diagram of the uterine horns of a pregnant mouse at term. The intrauterine position of female fetuses is determined at Caesarian delivery just before normal parturition. For the experiments described here only positioning relative to male fetuses was used to classify females. Females were classified as $2 \mathrm{M}$ if they developed between two male fetuses, $1 \mathrm{M}$ if they developed next to one male fetus, and $0 \mathrm{M}$ if they did not develop next to any male fetuses. Female mouse fetuses have higher blood concentrations of oestradiol than males, and 0M-male and $0 \mathrm{M}$-female fetuses have higher blood concentrations of oestradiol than do $2 \mathrm{M}$-fetuses of the same sex (unpublished observation), and this has led to the hypothesis that proximity to female fetuses is as important as proximity to male fetuses in mediating differences due to intrauterine position. A revised classification scheme is therefore now used in which $1 \mathrm{M}$-females develop between a male and a female fetus, and $0 \mathrm{M}$-females develop between 2 female fetuses.

female mice can mature reproductively in an appropriate social environment (Bronson \& Desjardins, 1974). Female mice do not differ in body weight at weaning as a function of prior intrauterine position (vom Saal \& Bronson, 1978; Kinsley et al., 1986a). The animals used in these experiments also did not differ significantly (ANOVA; $P>0.1$ ) in body weight at 24 or 25 days of age. For example, on Day 24 the mean ( \pm s.e.m.) weight (in g) of the females used in the following studies was: $0 \mathrm{M}$ females $=12.8 \pm 0.2 ; 1 \mathrm{M}$ females $=12.4 \pm 0.1 ; 2 \mathrm{M}$ females $=12.4 \pm 0.2$.

In all experiments in which males were present either to mate with the females or to induce regular oestrous cycles, adult IM-males (that had developed in utero between a male and a female fetus) were used. The purpose of using only 1M-males was to minimize any variance due to males in these experiments. Intrauterine position accounts for variation among male mice and rats in a broad range of reproductive characteristics, including sexual activity (vom Saal et al., 1983; vom Saal, 1989).

Animal housing. Housing typically consisted of $18 \times 29 \times 13 \mathrm{~cm}$ polypropylene shoe-box cages. In addition, $30 \times 30 \times 15 \mathrm{~cm}$ experimental cages with a wire partition dividing the cage into two compartments of equal size were used in experiments in which a male was needed to accelerate oestrous cycles; this caging system allows the male to induce the females to cycle regularly without allowing mating. Aspen shavings served as bedding material. Animal rooms were maintained at $23 \pm 1^{\circ} \mathrm{C}$ on a 12-h light cycle with lights on at $08: 00 \mathrm{~h}$. Vaginal smears were obtained between 13:00 and 15:00 h. Females were examined for copulatory plugs at 08:00 h.

Statistical analyses. In many of these experiments there was more than one female per cage at the time of data collection. Before comparing the data from the $0 \mathrm{M}, \mathrm{IM}$ and $2 \mathrm{M}$ females by ANOVA, I determined whether each female was cyclic or mating independently of the other females in the cage. A one-way ANOVA was therefore conducted for each dependent measure using cage as the main effect to determine whether the variation within each cage was the same as the variation between cages. If the $F$ value did not lead to rejection of the null hypothesis at 
$P<0.05$, then the data for all females within a cage were considered independent and analysed by the appropriate ANOVA. In none of the following experiments were significant cage effects found for any variable measured (nor was there a trend towards significance). Post-hoc comparisons were made using Fisher's LSD test.

\section{Detailed Methods, Results and Discussion}

\section{Experiment 1}

The purpose of this experiment was to examine whether the generality concerning the requirement that male mice be present for females to enter puberty at a young age and then exhibit regular oestrous cycles applied equally to females from different intrauterine positions. The age at vaginal opening, first vaginal oestrus, and vaginal smear characteristics during early adolescence (up to 45 days of age) were therefore examined in $0 \mathrm{M}$ - and $2 \mathrm{M}$-female mice housed individually in a malefree environment.

\section{Methods and results}

The $0 \mathrm{M}$ and $2 \mathrm{M}$ females (26/intrauterine position) were individually housed when 25 days old (birth date: 5-16 April) in $18 \times 29 \times 13 \mathrm{~cm}$ mouse cages in a room that did not contain any males. Vaginal smears were obtained daily between 13:00 and 15:00 h beginning at vaginal opening and ending when the females were 45 days old. $0 \mathrm{M}$ - and $2 \mathrm{M}$-females did not differ significantly in the age at vaginal opening, although $0 \mathrm{M}$-females tended to exhibit vaginal opening at a slightly younger age (29.2 \pm 0.3 days) than did $2 \mathrm{M}$-females $(30.1 \pm 0.3$ days; $\mathrm{F}(1,50)=3.7, P=0.06)$.

$0 \mathrm{M}$ - and $2 \mathrm{M}$-females did not differ in the age at which the first vaginal oestrus was observed. Five 0M-females and $52 \mathrm{M}$-females did not exhibit vaginal oestrus by 45 days of age, and these females were assigned a value of 45 days for the first oestrus $(260 \mathrm{M}$-females $=35 \cdot 6 \pm 1 \cdot 2$ days old; $262 \mathrm{M}$-females $=37 \cdot 4 \pm 1 \cdot 1$ days old; ANOVA, $P>0 \cdot 1$ ). Of the 26 females per intrauterine position, $100 \mathrm{M}$-females (39\%) and $142 \mathrm{M}$-females (54\%) exhibited two pro-oestrus-oestrus sequences (one 'cycle') between vaginal opening and 45 days of age. The interval between vaginal oestrus differed significantly for this subset of $100 \mathrm{M}$ - and $142 \mathrm{M}$-females $(0 \mathrm{M}$-females $=$ $10 \cdot 3 \pm 1 \cdot 1$ days; $2 \mathrm{M}$-females $=7 \cdot 1 \pm 0 \cdot 6$ days; $\mathrm{F}(1,22)=6 \cdot 7, P<0 \cdot 05)$.

When the females were 45 days old, males housed in separate shoe box cages were placed next to the cages containing the females to determine whether $0 \mathrm{M}$ - and $2 \mathrm{M}$-females would respond equally to oestrous cycle-accelerating cues produced by male mice. The males were housed in separate cages (rather than being in the same cage separated by a wire screen) to increase the possibility of detecting differences between $0 \mathrm{M}$ - and $2 \mathrm{M}$-females in the sensitivity to the presence of males. Specifically, at 45 days of age, the cages containing the individually-housed $0 \mathrm{M}$ - and $2 \mathrm{M}$-females were placed 5-6 cages per row on one side of a $60-\mathrm{cm}$-wide stainless steel rack, and inviduallyhoused adult $1 \mathrm{M}$-males were placed $7 /$ row on each shelf containing a row of females, but on the other side of the rack. Each cage containing a female thus had a cage with a male and at least one cage with a female next to it. Vaginal smears were obtained from these females until each female had exhibited two complete oestrous cycles. The first day of cornified cells was counted as Day 1 of the cycle.

After being placed next to cages containing males at 45 days of age, all $0 \mathrm{M}$ - and $2 \mathrm{M}$-females immediately began exhibiting regular oestrous cycles. The first two oestrous cycles exhibited by the $0 \mathrm{M}$-females were significantly shorter $(5.5 \pm 0.2$ days) than those exhibited by the $2 \mathrm{M}$-females $(6 \cdot 1 \pm 0.2$ days; $\mathrm{F}(1,50)=4.9, P<0.05)$.

\section{Discussion}

The first vaginal oestrus is equally delayed in $0 \mathrm{M}$ - and $2 \mathrm{M}$-females in the absence of stimulation by a male or his urine. In fact, about $25 \%$ of the females did not attain vaginal oestrus by 45 days of 
age. In the absence of male stimulation, the $2 \mathrm{M}$-females that did complete an oestrous cycle between first vaginal oestrus and $\mathbf{4 5}$ days of age had shorter cycles than did $0 \mathrm{M}$-females. In fact, in the absence of males, over one-third (9/26) of the $2 \mathrm{M}$-females exhibited an oestrous cycle that was typical for 2M-females at any age (5-7 days in length; vom Saal \& Bronson, 1980b), while only 3 of $260 \mathrm{M}$-females exhibited a 'cycle' 5-7 days in length. It therefore appears that slightly more $2 \mathrm{M}$ than OM-females will exhibit a 'regular' oestrous cycle after the first vaginal oestrus in the absence of males. Prior studies have shown that, in the absence of males, vaginal oestrus does not correlate with ovulation in peripubertal CF-1 female mice (Stiff et al., 1974; Perrigo \& Bronson, 1983). Further studies in which ovulation was confirmed by the presence of corpora lutea and tubal ova would thus be required before these findings could be interpreted as indicating that true ovulatory cycles had actually occurred in any of these females.

Placing males in separate cages next to the cages containing the females beginning at 45 days of age led to regular oestrous cycles being exhibited by all females: $0 \mathrm{M}$-females had significantly shorter oestrous cycles than $2 \mathrm{M}$-females. For this difference between $0 \mathrm{M}$ - and $2 \mathrm{M}$-females in oestrous cycle length to be observed during adolescence, the presence of males is therefore required; this effect appears to be mediated via the accessory olfactory system (Lomas \& Keverne, 1982). However, while the shorter oestrous cycles in $0 \mathrm{M}$-females are only observed if male mice are present before 5 months of age, after this age $0 \mathrm{M}$-female mice continued to exhibit significantly shorter oestrous cycles than $2 \mathrm{M}$-females even when individually housed in a male-free room (vom Saal \& Bronson, 1980b; vom Saal \& Finch, 1988).

\section{Experiment 2}

This experiment examined the age at puberty in females from different intrauterine positions using two methods: (1) the age at first ovulation and mating when $0 \mathrm{M}-$ and $2 \mathrm{M}$-females were housed individually in a cage with an adult male, and (2) the age at first vaginal oestrus and length of subsequent oestrous cycles in $0 \mathrm{M}$ - and $2 \mathrm{M}$-females when placed individually across a wire barrier from an adult male. The objective was to provide background information (before conducting the next experiment) concerning the relationship between prior intrauterine position and the timing of puberty in the presence of a male but in absence of the inhibitory effects of other females.

\section{Methods and results}

Part 1. In this part of this experiment 0M-, 1M- and 2M-females (20-26/intrauterine position) were housed individually in $18 \times 29 \times 13 \mathrm{~cm}$ cages with an adult male when 25 days old (birth date: 15-19 December). The animals were examined daily for the age at vaginal opening and the age at first mating, indicated by the presence of a copulatory plug. The females were allowed to deliver their litters to verify that ovulation and fertilization had occurred. The number of young produced by the $0 \mathrm{M}$ - and $2 \mathrm{M}$-females was not determined, since previous studies have revealed that differences between $0 \mathrm{M}$ - and $2 \mathrm{M}$-females in the production of young are observed during middle life and not in young adulthood (vom Saal \& Bronson, 1978; vom Saal \& Moyer, 1985).

Age at vaginal opening did not differ as a function of intrauterine position (mean age ( \pm s.e.m.) in days: $0 \mathrm{M}$-females $=30 \cdot 3 \pm 0.3 ; 1 \mathrm{M}$-females $=30.4 \pm 0.3 ; 2 \mathrm{M}$-females $=30.0 \pm 0.4$ ). The overall ANOVA on the data for age at mating was not statistically significant (ANOVA; $P=0 \cdot 17$ ). However, a post-hoc comparison of the means was still conducted based on the hypothesis that $0 \mathrm{M}$-females would enter puberty earlier than $2 \mathrm{M}$-females when individually housed with a male, while the age at puberty for $1 \mathrm{M}$-females was predicted to be intermediate between $0 \mathrm{M}$ - and $2 \mathrm{M}$-females (vom Saal, 1981). The post-hoc comparison revealed that $0 \mathrm{M}$-females mated at a significantly younger age than did $2 \mathrm{M}$-females, while $1 \mathrm{M}$-females did not differ significantly from $0 \mathrm{M}$ - or 2M-females (Fig. 2). 


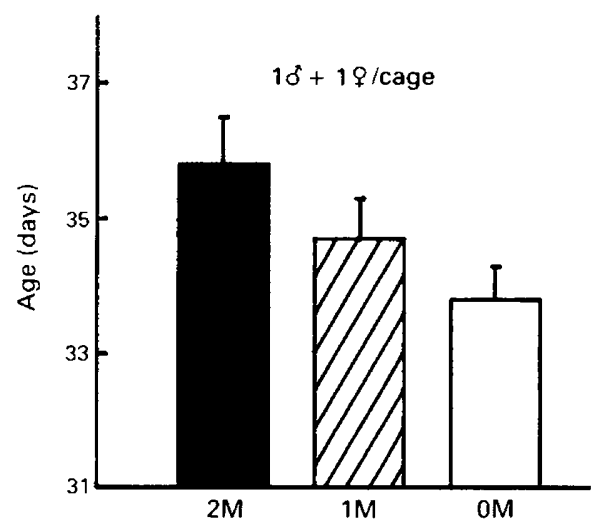

Fig. 2. The mean ( \pm s.e.m.) age at which a copulatory plug was found (indicative of ovulation and oestrus signalling puberty) in female mice housed individually with males beginning at 25 days of age in Exp. 2 (Part 1). The females were examined each morning at 08:00 h. Ovulation was verified by determing the age at parturition. $0 \mathrm{M}$-females $(\mathrm{N}=20)$ differed significantly from $2 \mathrm{M}$-females $(\mathrm{N}=20)$, while $1 \mathrm{M}$-females $(\mathrm{N}=26)$ did not differ significantly from either $0 \mathrm{M}$ - or $2 \mathrm{M}$-females.

The mean age at delivery for these females was not significantly different, although the $0 \mathrm{M}$-females tended to deliver pups at a younger age than the $1 \mathrm{M}$ - or $2 \mathrm{M}$-females $(19 / 20$ of $0 \mathrm{M}$-, $25 / 26$ of $1 \mathrm{M}$-, and $19 / 20$ of $2 \mathrm{M}$-females delivered litters: $0 \mathrm{M}$-females $=54 \cdot 0 \pm 0.7$ days old; $1 \mathrm{M}$-females $=55 \cdot 1 \pm 0.6$ days old; $2 \mathrm{M}$-females $=55 \cdot 1 \pm 0.6$ days old).

Part 2. In the second part of the experiment $0 \mathrm{M}$-females $(\mathrm{N}=18)$ and $2 \mathrm{M}$-females $(\mathrm{N}=19)$ were placed individually at 25 days of age (birth date: 15-19 December) into one side of a $30 \times 30 \times 15 \mathrm{~cm}$ cage that was divided by a wire mesh partition, and an adult $1 \mathrm{M}$-male was placed on the other side of the partition. The age at vaginal opening, age at first vaginal oestrus, and length of the first complete post-pubertal oestrous cycle were recorded.

The $2 \mathrm{M}$-females exhibited vaginal opening about a day earlier $(29.6 \pm 0.3$ days old $)$ than the $0 \mathrm{M}$-females $(30.9 \pm 0.3$ days old; $F(1,35)=7.6, P<0.01)$. In contrast, the $2 \mathrm{M}$-females exhibited first vaginal oestrus slightly later $(35.8 \pm 0.9$ days old) than the $0 \mathrm{M}$-females $(34.6 \pm 0.8$ days old; $P>0 \cdot 1)$. The length of the first post-pubertal oestrous cycle exhibited by the $0 \mathrm{M}-$ and $2 \mathrm{M}$-females differed significantly, with the mean ( \pm s.e.m.) cycle length for $0 \mathrm{M}$-females $(5 \cdot 1 \pm 0 \cdot 3$ days) being shorter than for $2 \mathrm{M}$-females $(6 \cdot 7 \pm 0.3$ days; $\mathrm{F}(1,35)=13 \cdot 37, P<0.001)$.

\section{Discussion}

This study revealed that, when paired with a male, $0 \mathrm{M}$-female mice attained puberty (ovulated and mated) at a significantly younger age than did $2 \mathrm{M}$-females, while $1 \mathrm{M}$-females were intermediate in the age at which they attained puberty. The age at puberty using either age at mating and ovulation (verified by subsequent birth of young) or age at first vaginal oestrus was very similar for $0 \mathrm{M}$ - and $2 \mathrm{M}$-females. This finding indicates that (1) first vaginal oestrus (but not vaginal opening) served as a reliable index of the age at first ovulation and (2) whether a male was inside the cage with a female or separated by a wire-mesh partition did not influence the timing of puberty in $0 \mathrm{M}$ - or $2 \mathrm{M}$-females. Tactile cues associated with physical contact between a male and a female therefore did not accelerate the age at which the pubertal ovulation occurred. In contrast, tactile and pheromonal stimulation act synergistically to induce uterine growth in peripubertal CF-1 female mice housed in the same caging systems described here (Bronson \& Maruniak, 1975).

A difference between $0 \mathrm{M}$ - and $2 \mathrm{M}$-females in the length of oestrous cycles has been reported previously (vom Saal \& Bronson, 1980b; vom Saal et al., 1981). This experiment confirmed that 
post-pubertal $0 \mathrm{M}$-female mice have shorter oestrous cycles than do $2 \mathrm{M}$-females when males are present to accelerate oestrous cycles and other females are not present. However, an interesting aspect of the results of this experiment, in comparison with Exp. 1 (after 45 days of age) is that, while $0 \mathrm{M}$-females had shorter oestrous cycles than did $2 \mathrm{M}$-females in both studies, the cycles exhibited by the $0 \mathrm{M}$-females housed individually in a separate cage next to the cage of a male in Exp. 1 were not as short as those exhibited by $0 \mathrm{M}-\mathrm{females}$ housed in the same cage across a wire barrier from a male in this experiment. For example, in this experiment, of the $180 \mathrm{M}$-females housed across a wire barrier from a male at puberty, only $3(17 \%)$ had cycles longer than 5 days, while $17(90 \%)$ of the $192 \mathrm{M}$-females had cycles longer than 5 days. In Exp. 1 in which the females and males were housed next to each other but in separate cages beginning at 45 days of age, for the two complete oestrous cycles that were monitored, $52 \%$ of the cycles exhibited by the $0 \mathrm{M}$-females and $77 \%$ of the cycles exhibited by the $2 \mathrm{M}$-females were greater than 5 days in length.

\section{Experiment 3}

The objective of this experiment was to examine whether prior intrauterine position would influence the sensitivity to and/or production of puberty and oestrous cycle-delaying cues in female mice using the same two paradigms as in Exp. 2. In both parts of the experiment two different combinations of 0M- and 2M-females were examined (Group 1:4 0M- and 12M-females per cage $v s$ Group 2: $42 \mathrm{M}$ - and $10 \mathrm{M}$-females per cage). The purpose of housing 1 female from one intrauterine position with 4 females from the opposite intrauterine position was to allow a determination of whether differences in the timing of puberty and length of subsequent oestrous cycles between $0 \mathrm{M}$ - and $2 \mathrm{M}$-females were due to differences in (1) the production of cues, (2) the sensitivity to cues, or (3) both the production of and sensitivity to cues that modulate these events. For example, a difference between the $0 \mathrm{M}$ - and $2 \mathrm{M}$-females within a cage would suggest a difference in sensitivity to the cues present in the particular cage, while a difference between caging conditions $(40 \mathrm{M}+12 \mathrm{M}$ vs $42 \mathrm{M}+10 \mathrm{M})$ would indicate a difference in the production of cues.

\section{Methods and results}

Before conducting the first part of this study in which a male was placed into a cage containing the 0M- and 2M-females, I determined whether CF-1 male mice would be able to inseminate more than one oestrous female per night (behavioural oestrus typically occurs during the dark phase of the light:dark cycle). Sexually-naive males (90 days old) were each housed with 3 ovariectomized, oestrogen and progesterone-treated females beginning at 17:00 h. The females were examined the next morning at 08:00 $\mathrm{h}$ for the presence of copulatory plugs. Of 22 males, 12 males inseminated all 3 females, 7 males inseminated 2 females, and 3 males inseminated 1 female. Since in the present study sexually-experienced males were used, it is likely that most of the males would have been able to inseminate 2 or more of the 5 females per cage if they entered oestrus on the same night.

Part 1 . The cages containing the $40 \mathrm{M}$ - and $12 \mathrm{M}$-females and the cages containing the $42 \mathrm{M}$ - and 1 $0 \mathrm{M}$-females ( 8 replicates each) were established when the females were 25 days old (birth date: $18-30$ December). An adult, stud 1M-male was placed into each cage. Each female was examined daily for vaginal opening and, subsequently, the presence of a copulatory plug. The females remained together until just before the expected date of delivery ( 20 days after mating), at which time each female was individually housed. Since all females within each cage mated within 16 days of the first female within a cage being inseminated, this procedure did not interfere with recording the age at first mating.

The overall ANOVA on age at vaginal opening revealed no significant interactions or main effects of housing condition or intrauterine position, although the $40 \mathrm{M}$-females in Group 1 experienced vaginal opening 2 days later than the $42 \mathrm{M}$-females in Group 2 (age in days: Group 1: $40 \mathrm{M}$-females $=33.0 \pm 0.5 ; 12 \mathrm{M}$-female $=32 \cdot 1 \pm 1 \cdot 0 ;$ Group 2: $42 \mathrm{M}$-females $=31 \cdot 0 \pm 0.4$; $10 \mathrm{M}$-female $=31.9 \pm 0.7$. 
The results presented in Fig. 3 reveal that, in the cages containing $40 \mathrm{M}$-females and 1 2M-female in Group 1, the age at first oestrus was significantly delayed relative to that in the 4 $2 \mathrm{M}$ - and $10 \mathrm{M}$-females in Group 2 (main effect for group: $\mathrm{F}(1,73)=11.8, P<0.001$ ). Post-hoc comparisons revealed that the $10 \mathrm{M}$-female housed with $42 \mathrm{M}$-females mated earlier than did the 4 $0 \mathrm{M}$-females housed with $12 \mathrm{M}$-female; no other comparisons were significantly different.

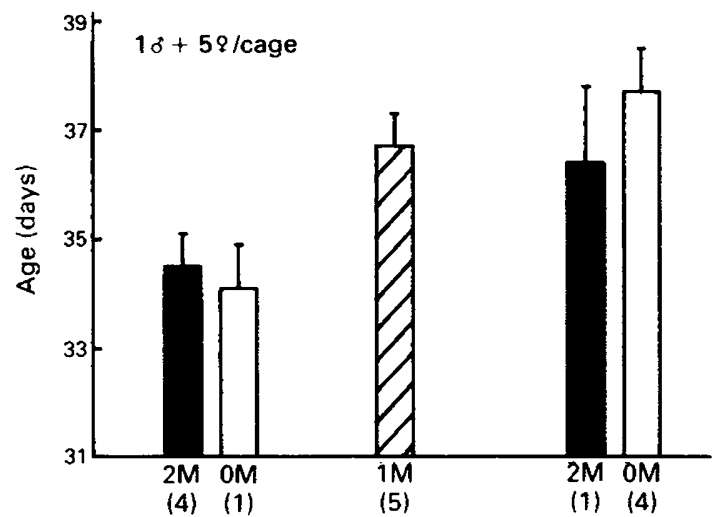

Fig. 3. The mean ( \pm s.e.m.) age at which a copulatory plug was found (indicative of ovulation and oestrus signalling puberty) in female mice housed 5/cage with males beginning at 25 days of age in Exp. 3 (Part 1). Three different groups of females were examined (8 replicates per housing condition): $42 \mathrm{M}$-females housed with $10 \mathrm{M}$-female, $51 \mathrm{M}$-females housed together, 4 0M-females housed with $12 \mathrm{M}$-female. The females were examined each morning at 08:00 $\mathrm{h}$. Ovulation was verified by determing the age at parturition. Post-hoc comparisons revealed that the $40 \mathrm{M}$-females in Group 1 mated significantly later than did the 10M-female in Group 2. No other group means differed significantly.

The age at delivery of young was also determined to verify that fertilization had occurred and was also found to differ significantly as a function of housing condition (age at delivery for the 4 $0 \mathrm{M}$-females $(57 \cdot 1 \pm 0.8$ days) and $12 \mathrm{M}$-female (56.3 \pm 1.8 days) in Group 1 and the $42 \mathrm{M}$-females $(54.2 \pm 0.8$ days) and $10 \mathrm{M}$-female $(54.5 \pm 0.9$ days) in Group $2 ; \mathrm{F}(1,68)=6.8, P<0.05 ; 2$ $0 \mathrm{M}$ - and $52 \mathrm{M}$-females did not deliver young).

Five $1 \mathrm{M}$-females were also housed in a cage with an adult $1 \mathrm{M}$-male ( 8 replicates). The mean ( \pm s.e.m.) age at vaginal opening was $31.0 \pm 0.4$ days. These females tended to ovulate and mate later than did the females in the $42 \mathrm{M}$ and $10 \mathrm{M}$ cages, but earlier than the females in the $40 \mathrm{M}$ and 1 $2 \mathrm{M}$ cages (Fig. 3 ). The age at delivery of young for the $1 \mathrm{M}$-females housed $5 /$ cage (37/40 females) was $56.6 \pm 0.6$ days.

The $1 \mathrm{M}$-females housed individually with a male in Exp. 2 were compared for the age at vaginal opening and mating with the $1 \mathrm{M}$-females housed 5/cage with a male in this experiment (all of these females were born and tested at the same time). No difference in the age at vaginal opening (30.4 \pm 0.3 days in individually housed mice, $31.0 \pm 0.4$ days in group housed mice) based on the number of $1 \mathrm{M}$-females per cage was observed. However, the individually housed $1 \mathrm{M}$-females ovulated and mated at a significantly younger age $(34.7 \pm 0.6$ days) than did the $1 \mathrm{M}$-females housed $5 /$ cage $(36.7 \pm 0.6$ days; $F(1,63)=4.4, P<0.05)$.

Part 2. In the second part of this experiment, $0 \mathrm{M}$ - and $2 \mathrm{M}$-females were housed together when 25 days old (birth date: 8-16 April) in groups (8 replicates each) of $40 \mathrm{M}$ - and $12 \mathrm{M}$-females per cage (Group 1) or $42 \mathrm{M}$ - and $10 \mathrm{M}$-females per cage (Group 2) across a wire barrier from an adult $1 \mathrm{M}$-male mouse. Beginning at vaginal opening, vaginal smears were examined daily. 
There were no differences between any of the groups in the age at which vaginal opening occurred (Group 1: $40 \mathrm{M}=30.0 \pm 0.4$ days; $12 \mathrm{M}=28.3 \pm 0.6$ days; Group 2: $42 \mathrm{M}=29.7 \pm 0.3$ days; $10 \mathrm{M}=30 \cdot 1 \pm 0 \cdot 4$ days). The age at first vaginal oestrus was $35 \cdot 4 \pm 1 \cdot 2$ days for $40 \mathrm{M}-$ and $31.5 \pm 1.6$ days for $12 \mathrm{M}$-females in Group 1 and $30.8 \pm 0.7$ days for $10 \mathrm{M}$ - and $34.1 \pm 1.0$ days for $42 \mathrm{M}$-females in Group 2. An overall ANOVA on the age at first oestrus revealed a significant effect of housing condition $[\mathrm{F}(1,70)=5.2, P<0.025]$. Post-hoc comparisons revealed that the age at first oestrus was significantly earlier for the $10 \mathrm{M}$-female housed with $42 \mathrm{M}$-females than for the 4 $0 \mathrm{M}$-females housed with the $12 \mathrm{M}$-female; no other group means differed significantly.

An overall ANOVA on the length of the first 4 post-pubertal oestrous cycles revealed a significant interaction between cycle number $(1-4)$ and prior intrauterine position $[F(3,84)=3 \cdot 2$, $P<0.05$; see Fig. 4]. Post-hoc analysis revealed that, in the cages containing $40 \mathrm{M}$-females, all females exhibited a prolonged first oestrous cycle, including the $12 \mathrm{M}$-female housed with the 4 $0 \mathrm{M}$-females. The $42 \mathrm{M}$-females in Group 2 had a significantly shorter first post-pubertal oestrous cycle than did the $12 \mathrm{M}$-female in Group 1 housed in the cages containing $40 \mathrm{M}$-females; the 4 $2 \mathrm{M}$-females also had a shorter first post-pubertal oestrous cycle than did the $10 \mathrm{M}$-female housed in the same cage. During adolescence the oestrous cycles of all $0 \mathrm{M}$-females decreased in length. By young adulthood (Cycle 4; Fig. 4), the $40 \mathrm{M}$-females in Group 1 had significantly shorter cycles than did either the $12 \mathrm{M}$-female housed with them or the $42 \mathrm{M}$-females in Group 2 . For the $2 \mathrm{M}$-females in both groups, the second oestrous cycle was shorter than the first post-pubertal oestrous cycle, but no subsequent change in oestrous cycle length was observed.

\section{Discussion}

The results of the first and second parts of this experiment were consistent in that, using both mating or first vaginal oestrus to assess the age at puberty, the $10 \mathrm{M}$-female housed in cages with 4 $2 \mathrm{M}$-females entered puberty earlier than did the $40 \mathrm{M}$-females housed with $12 \mathrm{M}$-female. In contrast, the $2 \mathrm{M}$-females in these different housing conditions did not differ significantly from each other. The results of the second part of the experiment revealed that, in the cages containing 4 $0 \mathrm{M}$ - and $12 \mathrm{M}$-females, the $0 \mathrm{M}$ - and $2 \mathrm{M}$-females also exhibited a significantly prolonged first postpubertal oestrous cycle. In contrast, in the cages containing the $42 \mathrm{M}$-females and $10 \mathrm{M}$-female, there was a significant interaction between intrauterine position and the length of oestrous cycles throughout adolescence.

It appears that, if the proportion of $0 \mathrm{M}$-females in an environment is high, the pubertydelaying and oestrous cycle-prolonging cues emitted by $0 \mathrm{M}$-females are potent enough to cause $2 \mathrm{M}$-females in the same environment to enter puberty late and then exhibit a prolonged postpubertal oestrous cycle (Fig. 3; Fig. 4a). In environments with predominantly $2 \mathrm{M}$-females (as in Group 2, Part 1), the intensity of the cues in the environment is not great enough to produce a delay in $0 \mathrm{M}$ - or $2 \mathrm{M}$-females in the age at which they first ovulate and mate. In contrast, in the environment containing $42 \mathrm{M}$-females and $10 \mathrm{M}$-female (Fig. $4 \mathrm{~b}$ ), the cues were potent enough to produce a greatly prolonged first post-pubertal oestrous cycle in the $0 \mathrm{M}$-female, while much less of an effect was observed in the $2 \mathrm{M}$-females. This latter finding suggests that $0 \mathrm{M}$-females are more sensitive than $2 \mathrm{M}$-females to the presence of less potent cues emitted by $2 \mathrm{M}$-females in terms of the length of oestrous cycles after puberty, but not in the age at which the first ovulation occurs.

Taken together, the results of this experiment suggest that, during the peripubertal period, $0 \mathrm{M}$-females emit a more potent oestrous cycle-delaying pheromone than do $2 \mathrm{M}$-females, and $0 \mathrm{M}$-females are also more sensitive to the presence of the pheromone than are $2 \mathrm{M}$-females. This experiment also replicated the finding that, by adulthood, $0 \mathrm{M}$-female mice have significantly shorter oestrous cycles than do $2 \mathrm{M}$-females, with or without other females in the environment (vom Saal \& Bronson, 1980b; vom Saal et al., 1981). 


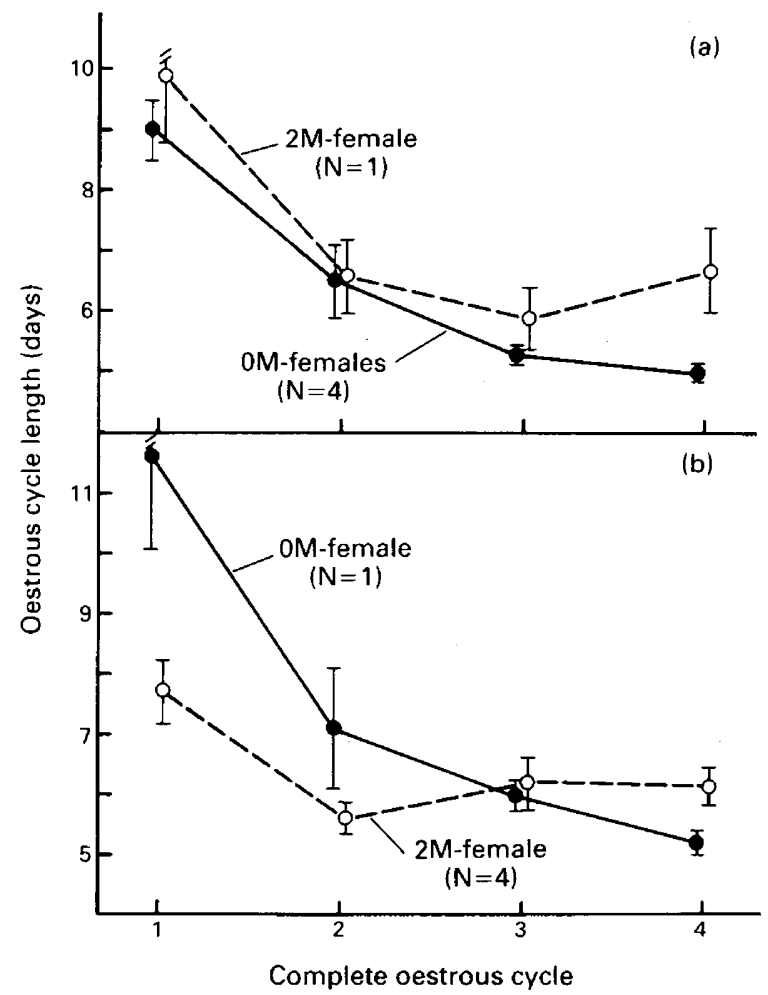

Fig. 4. The mean ( \pm s.e.m.) length of the first 4 complete oestrous cycles beginning with the first vaginal oestrus for females examined in Exp. 3 (Part 2). Day 1 of each cycle was the day on which a vaginal smear contained predominantly cornified epithelial cells. Females (4 $0 \mathrm{M}$ and 1 $2 \mathrm{M}$ in Group 1; $42 \mathrm{M}$ and $10 \mathrm{M}$ in Group 2) were housed 5/cage across a wire partition from an adult male (8 replicates per housing condition). In Group 1 (a), the first post-pubertal oestrous cycle was significantly longer than subsequent cycles in the $0 \mathrm{M}$ - and $2 \mathrm{M}$-females. In addition, the 4 th complete cycle exhibited by the $0 \mathrm{M}$-females was significantly shorter than that exhibited by the $2 \mathrm{M}$-females. In Group 2 (b) the first cycle was significantly longer in $0 \mathrm{M}$-females than in $2 \mathrm{M}$-females. There was a significant decrease in cycle length during adolescence (Cycles 1-4) in $0 \mathrm{M}$-females. A significant change in cycle length occurred between the 1 st and 2 nd cycles in 2M-females.

\section{Experiment 4}

\section{Introduction}

The objective of this experiment was to examine further the prolongation of oestrous cycles after puberty in grouped $0 \mathrm{M}$ - and $2 \mathrm{M}$-females. Unlike the previous experiment, the animals were housed with equal numbers of $0 \mathrm{M}$ - and $2 \mathrm{M}$-females in each cage to determine whether the greater prolongation in the length of oestrous cycles after puberty in $0 \mathrm{M}$-females than in $2 \mathrm{M}$-females would still be observed. Since intrauterine position by sex is a random event (vom Saal, 1981), in natural populations of mice there should be equal numbers of weanling $0 \mathrm{M}$ - and $2 \mathrm{M}$-females (as defined in Fig. 1).

\section{Methods and results}

Three 0M- and $32 \mathrm{M}$-females were matched for weight and placed together when 33 days old (birth date: $23-31$ January) in a $30 \times 30 \times 15 \mathrm{~cm}$ cage (6 replicates) separated into two equal 
compartments by a wire screen. An adult $1 \mathrm{M}$-male was placed on one side of the screen and the females were placed on the other side. The animals were examined by vaginal lavage every day beginning at 33 days of age for 4 complete oestrous cycles.

There was no significant difference in the age at which the first vaginal smear indicative of ovulation was observed, although the $0 \mathrm{M}$-females tended to exhibit first vaginal oestrus later than did the $2 \mathrm{M}$-females: $0 \mathrm{M}=37.8 \pm 1.4$ days; $2 \mathrm{M}=35.6 \pm 0.6$ days; $\mathrm{F}(1,34)=2 \cdot 0, P=0 \cdot 16$. Vaginal opening occurred before Day 33 in these females.

Analysis of the length of the first 4 oestrous cycles revealed a significant intrauterine position by cycle interaction $[\mathrm{F}(3,102)=15 \cdot 1, P<0.001]$. Post-hoc comparisons of the means presented in Fig. 5 revealed that, for the first complete oestrous cycle, the mean cycle length for $0 \mathrm{M}$-females was significantly longer than for $2 \mathrm{M}$-females. However, by the 4 th complete cycle, the mean cycle length for $0 \mathrm{M}$-females was significantly shorter than for $2 \mathrm{M}$-females. There was a significant reduction in cycle length between the first and subsequent cycles for both $0 \mathrm{M}-$ and $2 \mathrm{M}$-females. The 4 th cycle exhibited by $0 \mathrm{M}$-females was significantly shorter than all other cycles, while the $2 \mathrm{nd}$, 3rd and 4th cycles exhibited by $2 \mathrm{M}$-females were not significantly different.

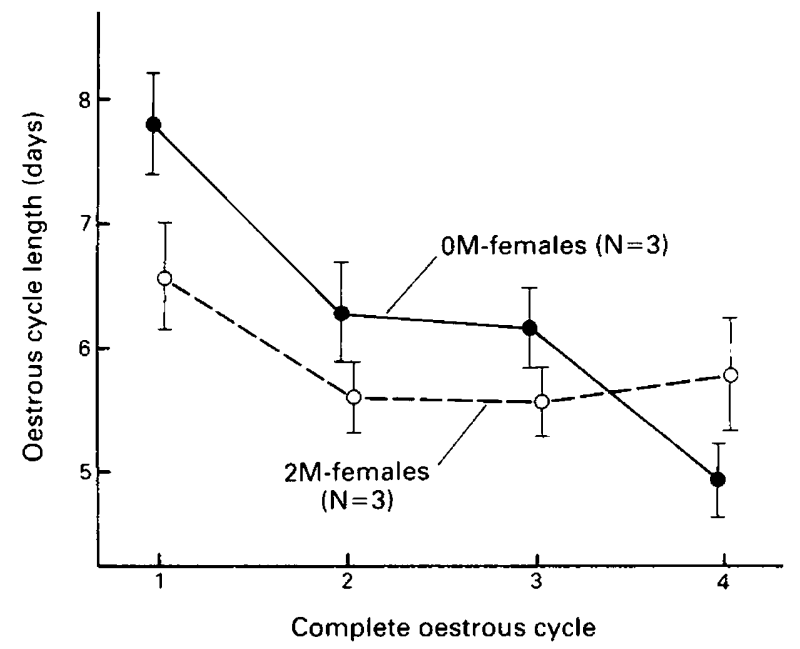

Fig. 5. The mean ( \pm s.e.m.) length of the first 4 complete oestrous cycles beginning with the first vaginal oestrus for females examined in Exp. 4. Three 0M-females and $32 \mathrm{M}$-females were housed together $6 /$ cage ( 6 replicates) across a wire partition from an adult male. There was a significant decrease in cycle length during adolescence in $0 \mathrm{M}$-females: $0 \mathrm{M}$-females had a significantly longer first post-pubertal cycle and a shorter 4th post-pubertal cycle than did $2 \mathrm{M}$-females. A significant decrease in cycle length occurred between the 1 st and 2 nd oestrous cycles in $2 \mathrm{M}$-females.

\section{Discussion}

The present results support the conclusion that one factor in the difference between $0 \mathrm{M}$ - and $2 \mathrm{M}$-females in cycle length during early adolescence is a differential sensitivity to the cues that prolong cycles in adolescent female mice. This conclusion is based on the fact that all females within a cage were exposed to cues of the same intensity but differed in their response to the cues. However, it cannot be ruled out that behavioural interactions between the $0 \mathrm{M}$ - and $2 \mathrm{M}$-females might have contributed to differences in cycle length. For example, $2 \mathrm{M}$-female mice exhibit more mounting and attacks towards other females than do 0M-females (vom Saal \& Bronson, 1978; Rines \& vom Saal, 1984). 


\section{General Discussion}

The age at first oestrus was assessed by either examining vaginal cytology (first vaginal oestrus) or by allowing females to mate with males and subsequently produce young. These methods of determining the age at which the pubertal ovulation occurred yielded fairly consistent findings for $2 \mathrm{M}$-females, regardless of their social environment. For example, when $42 \mathrm{M}$-females and 1 OM-female were housed per cage in Exp. 3 with a male behind a wire partition to inhibit mating or in the cage with the females to allow mating, the mean age at first vaginal oestrus for the $2 \mathrm{M}$-females was $34 \cdot 1$ days and the age at first ovulation and mating was 34.5 days. The mean age at which $2 \mathrm{M}$-females housed individually with a male in Exp. 2 ovulated and mated was 35.8 days. When $32 \mathrm{M}$ - and $30 \mathrm{M}$-females were housed per cage in Exp. 4, first vaginal oestrus occurred in $2 \mathrm{M}$-females at 35.6 days. Thus the age at which the first ovulation signalling puberty occurred in $2 \mathrm{M}$-females was not delayed by the presence of other females in environments in which puberty in IM- and $0 \mathrm{M}$-females was delayed.

A significant delay in puberty occurred in $1 \mathrm{M}$-females when grouped as $51 \mathrm{M}$-females per cage with a male (Exp. 3) as opposed to being housed individually with a male (Exp. 2). However, the greatest effect of the social environment was seen in $0 \mathrm{M}$-females. When housed individually with a male in Exp. 2, 0M-females mated at a mean of 33.8 days of age, but when housed in groups of 4 $0 \mathrm{M}$ - and $12 \mathrm{M}$-females per cage with a male in Exp. 3, the 0M-females mated at 37.7 days of age. In this last experiment the mean age at mating (36.7 days) for the $12 \mathrm{M}$-female housed together with 4 $0 \mathrm{M}$-females also was delayed relative to $2 \mathrm{M}$-females in any other housing condition in which males were present. The conclusion is that $0 \mathrm{M}$-females are more sensitive to puberty-delaying cues (presumably, these are pheromonal cues) than are $2 \mathrm{M}$-females (1M-females are intermediate). In an environment containing many $2 \mathrm{M}$-females, the $2 \mathrm{M}$-females entered puberty earlier than when mostly $0 \mathrm{M}$-females were present. This finding indicates that $0 \mathrm{M}$-females produce more potent puberty-delaying cues than do $2 \mathrm{M}$-females.

The 0M- and 2M-females housed individually in a male-free environment in Exp. 1 exhibited vaginal opening at an age similar to that of females housed in the same cage with a male or across a wire barrier from a male in Exp. 2. Vaginal opening has been used as a marker of puberty in house mice in some studies. The present studies confirm that vaginal opening is not a marker of the pubertal ovulation (see also: Stiff et al., 1974; Perrigo \& Bronson, 1983).

It is well documented that there is a developmental shift in the dominance of female to female $v s$ male to female cues during adolescence in mice (Vandenbergh, 1973). During early adolescence (before 50 days of age) cues produced by grouped females override the puberty and oestrous cycleaccelerating action of cues produced by males, but gradually this relationship reverses, and by late adolescence (55-60 days of age), grouping of females ceases to interfere with the oestrous cycleaccelerating action of a male. This dramatic developmental shift occurred during adolescence to a much greater degree in $0 \mathrm{M}$-females than in $2 \mathrm{M}$-females.

A dramatic effect of the presence of other females on the length of oestrous cycles during early adolescence was observed in all $0 \mathrm{M}$-females examined. The first post-pubertal oestrous cycle exhibited by $0 \mathrm{M}$-females was 8-10 days long in the presence of other females from any intrauterine position (Exps 3 and 4 above; vom Saal et al., 1981). The results of Exps 3 and 4 also revealed that, if there were fewer than $40 \mathrm{M}$-females per cage, $2 \mathrm{M}$-females did not show a marked prolongation of the first post-pubertal oestrous cycle relative to the prolonged cycle they would exhibit even if individually housed. If oestrous cycle-prolonging cues in the environment were potent enough due to the presence of $40 \mathrm{M}$-females in the cage, $2 \mathrm{M}$-females did have the ability to respond to the cues by exhibiting as prolonged a post-pubertal oestrous cycle as in $0 \mathrm{M}$-females. The conclusion is that (1) $2 \mathrm{M}$-females produce less potent cues than $0 \mathrm{M}$-females, since only when housed in a cage containing mostly $0 \mathrm{M}$-females did $2 \mathrm{M}$-females show a prolonged first post-pubertal oestrous cycle, (2) $2 \mathrm{M}$-females are also less sensitive to oestrous cycle-prolonging cues (presumably these are pheromonal cues) than are $0 \mathrm{M}$-females. 
In contrast to the above findings, oestrous cycles of $0 \mathrm{M}$-females averaged about 4-5 days in length when the females were housed individually across a wire barrier from a male either immediately after puberty (Exp. 2) or in adulthood (Exps 3 and 4). An important aspect of the effects of intrauterine position on oestrous cycles in mice is that, when examined at 150 days of age (in adulthood), $0 \mathrm{M}$-females had significantly shorter cycles than $2 \mathrm{M}$-females when housed individually in a male-free environment (vom Saal \& Bronson, 1980b). This finding demonstrates that: (1) the requirement that males or male urine be present for female mice to exhibit regular oestrous cycles (revealed in Exp. 1) is lost by 150 days of age (also see Nelson et al., 1982), and (2) intrauterine position influences the intrinsic timing of oestrous cycles in fully adult females in the absence of any differences due to intrauterine position in sensitivity to pheromonal cues.

In an environment containing mostly $0 \mathrm{M}$-females, the onset of puberty was delayed and subsequent oestrous cycles were prolonged in all females (regardless of prior intrauterine position) relative to an environment containing mostly $2 \mathrm{M}$-females. In cages containing mostly $2 \mathrm{M}$ females, there was no effect of grouping on the timing of puberty in any female (regardless of prior intra-uterine position) and only a very slight effect on the length of subsequent oestrous cycles in other $2 \mathrm{M}$-females. The expected proportion of females from each intrauterine position is about $20 \% 0 \mathrm{M}, 20 \% 2 \mathrm{M}$ and $50 \% 1 \mathrm{M}$, with the remainder of animals at the ends of the horns not being able to be classified using this scheme (vom Saal, 1981). In an environment containing this proportion of $0 \mathrm{M}-, 1 \mathrm{M}$ - and $2 \mathrm{M}$-females, the $2 \mathrm{M}$-females should be the least sensitive to the puberty-delaying and oestrous cycle-prolonging effects of other females, while 0M-females should be the most sensitive to these effects. Together with the finding that $2 \mathrm{M}$-female mice are more aggressive towards other females than are 0M-females (vom Saal \& Bronson, 1978), these findings lead to the hypothesis that $2 \mathrm{M}$-females are likely to have a reproductive advantage over $0 \mathrm{M}$ females at high population densities (vom Saal, 1984, 1989). Ims (1987) placed voles (Clethrionomys rufocanus) onto an island, and the major predictor of reproductive success in females was the number of male siblings present in the litter at birth, which is correlated with the likelihood of being either a $0 \mathrm{M}$ - or $2 \mathrm{M}$-female.

In some environments the difference in aggression (vom Saal \& Bronson, 1978) and spontaneous activity level (Kinsley et al., 1986b) between 0M- and 2M-females might result in $0 \mathrm{M}$-females being dispersed during adolescence or adulthood. I have proposed that this could lead to a shift in the age at which females remaining in the population first produce young and thus alter population dynamics (for reviews see: vom Saal, 1984, 1989).

Previous experiments have demonstrated that prior intrauterine position influences a wide range of traits in female mice, rats, gerbils and pigs (vom Saal, 1981, 1983, 1989; Clark \& Galef, 1988). Of particular relevance to the present findings are prior experiments identifying differences in stimulus characteristics between $0 \mathrm{M}$ - and $2 \mathrm{M}$-female mice. Significantly more males $(82 \%)$ entered a chamber containing a $0 \mathrm{M}$-female than a $2 \mathrm{M}$-female when given a choice (vom Saal \& Bronson, 1978; 1980a). Also, when sexually-receptive 0M- and 2M-female mice were placed together with a stud male, the $0 \mathrm{M}$-female was significantly more likely to be mated with first (Rines \& vom Saal, 1984). Wechman et al. (1982) proposed that differences in attractiveness between $0 \mathrm{M}$ - and $2 \mathrm{M}$-female mice might be mediated by differences in preputial gland function, since they reported a significant difference between $0 \mathrm{M}$ - and $2 \mathrm{M}$-females in preputial gland $\beta$-glucuronidase activity.

Clark \& Galef (1988) reported results in Mongolian gerbils that were similar to the present findings in Exp. 2, namely, that $0 \mathrm{M}$-females matured more rapidly than did $1 \mathrm{M}-$ or $2 \mathrm{M}$-females. However, there was also a biasing of the female offspring produced by the $0 \mathrm{M}-, 1 \mathrm{M}-$ and $2 \mathrm{M}$ females: the offspring of $1 \mathrm{M}$ - and $2 \mathrm{M}$-females were more likely to be late maturing than were the offspring of $0 \mathrm{M}$-females. The possibility of trans-generational biases in reproductive characteristics due to developmental events (see Christian \& Lemunyan, 1958), such as intrauterine position during fetal life, warrants further study in other litter-bearing mammals. 
Support was provided by NSF grant DCB 8518094 and the University of Missouri Research Council (University of Missouri Biomedical Research Support Grant from NIH). I thank J. Vandenbergh and G. Perrigo for comments during the preparation of this manuscript.

\section{References}

Bronson, F.H. (1979) The reproductive ecology of the house mouse. Quart. Rev. Biol. 54, 265-299.

Bronson, F.H. \& Coquelin, A. (1980) The modulation of reproduction by priming pheromones in house mice: speculations on adaptive function. In Chemical Signals, pp. 243-265. Eds D. Muller-Schwarze \& R. Silverstein. Plenum Press, New York.

Bronson, F.H. \& Desjardins, C. (1974) Circulating concentrations of FSH, LH, estradiol, and progesterone associated with acute, male-induced puberty in female mice. Endocrinology 94, 1658-1668.

Bronson, F.H. \& Macmillan, B. (1983) Hormonal responses to primer pheromones. In Pheromones and Reproduction in Mammals, pp. 175-197. Ed. J. Vandenbergh. Academic Press, New York.

Bronson, F.H. \& Maruniak, J.A. (1975) Male-induced puberty in female mice: evidence for a synergistic action of social cues. Biol. Reprod. 13, 94-98.

Christian, J.J. \& Lemunyan, C. (1958) Adverse effects of crowding on lactation and reproduction in mice and two generations of their progeny. Endocrinology 63, $517-529$.

Clark, M.M. \& Galef, B.G. (1988) Effects of uterine position on rate of sexual development in female Mongolian gerbils. Physiol. Behav. 42, 15-18.

Drickamer, L.C. (1974) Contact stimulation, androgenized females and accelerated sexual maturation in female mice. $J$. Reprod. Fert. 12, 101-110.

Drickamer, L.C. (1976) Effect of size and sex ratio of litter on the sexual maturation of female mice. $J$. Reprod. Fert. 46, 369-374.

Drickamer, L.C. (1977) Delay of sexual maturation in female mice by exposure to grouped females or urine from grouped females. J. Reprod. Fert. 51, $77-81$.

Drickamer, L.C. (1982) Acceleration and delay of first vaginal oestrus in female mice by urinary chemosignals: dose levels and mixing urine treatment sources. Anim. Behav. 30, 456-460.

Drickamer, L.C. (1986) Puberty-influencing chemosignals in house mice: ecological and evolutionary considerations. In Chemical Signals in Vertebrates, pp. 441-455. Eds D. Durall, D. Muller-Schwarze \& R. Silverstein. Plenum Press, New York

Gorski, R. (1979) The neuroendocrinology of reproduction: an overview. Biol. Reprod. 20, 111-127.

Ims, R. (1987) Determinants of competitive success in Clethrionomys rufocanus. Ecology 68, 1812-1818.

Kinsley, C., Miele, J., Konen Wagner, C., Ghiraldi, L., Broida, J. \& Svare, B. (1986a) Prior intrauterine position influences body weight in male and female mice. Horm. Behav. 20, 201-211.

Kinsley, C., Miele, J., Konen, C., Ghiraldi, L. \& Svare, B. (1986b) Intrauterine contiguity influences regulatory activity in adult female and male mice. Horm. Behav. 20, 7-12.
Lomas, D. \& Keverne, E.B. (1982) Role of the vomeronasal organ and prolactin in the acceleration of puberty in female mice. J. Reprod. Fert. 66, 101-108.

Massey, A. \& Vandenbergh, J.G. (1980) Puberty delay by a urinary cue from female house mice in feral populations. Science, N.Y. 209, 821-822.

McIntosh, T.K. \& Drickamer, L.C. (1977) Excreted urine, bladder urine, and the delay of sexual maturation in female house mice. Anim. Behav. 25, 999-1004.

Nelson, J., Felicio, L., Randall, P., Simms, C. \& Finch, C. (1982) A longitudinal study of estrous cyclicity in C57BL/6J mice. I. Cycle frequency, length and vaginal cytology. Biol. Reprod. 27, 327-339.

Perrigo, G.H. \& Bronson, F.H. (1983) Foraging effort, food intake, fat deposition and puberty in female mice. Biol. Reprod. 29, 455-463.

Rines, J.P. \& vom Saal, F.S. (1984) Fetal effects on sexual behavior and aggression in young and old female mice treated with estrogen and progesterone. Horm. Behav. 18, 117-129.

Rohde-Parfet, K., Ganjam, V., Lamberson, W., Rieke, A., vom Saal, F. \& Day, B. (1988) Effects of intrauterine position on reproductive behavior and performance in gilts. J. Anim. Sci. 66 (Suppl. 1), 234, Abstr. 43.

Ryan, K.D. \& Schwartz, N.B. (1980) Changes in serum hormone levels associated with male-induced ovulation in adult female mice. Endocrinology 106, 959-966.

Stiff, M.E., Bronson, F.H. \& Stetson, M.H. (1974) Plasma gonadotropins in prenatal and prepubertal female mice: disorganization of pubertal cycles in the absence of a male. Endocrinology 94, 492-496.

Vandenbergh, J.G. (1973) Acceleration and inhibition of puberty in female mice by pheromones. $J$. Reprod. Fert., Suppl. 19, 411-419.

Vandenbergh, J.G. (1983) Pheromonal regulation of puberty. In Pheromones and Reproduction in Mammals, pp. 95-110. Ed. J. Vendenbergh. Academic Press, New York.

Vandenbergh, J.G. \& Coppola, D.M. (1986) The physiology and ecology of puberty: Modulation by primer pheromones. In Advances in the Study of Behavior, pp. 71-107. Eds J. Rosenblatt, C. Beer \& M. Busskel. Academic Press, New York.

Vandenbergh, J.G., Drickamer, L.C. \& Colby, D.R. (1972) Social and dietary factors in the sexual maturation of female mice. J. Reprod. Fert. 28 , $297-405$.

vom Saal, F.S. (1981) Variation in phenotype due to random intrauterine positioning of male and female fetuses in rodents. J. Reprod. Fert. 62, 633-650.

vom Saal, F.S. (1983) The interaction of circulating estrogens and androgens in regulating mammalian sexual differentiation. In Hormones and Behavior in Higher Vertebrates, pp. 159-177. Eds J. Balthazart, E. Prove \& R. Giles. Springer Verlag, Berlin. 
vom Saal, F.S. (1984) The intrauterine position phenomenon: effects on physiology, aggressive behavior and population dynamics in house mice. In Prog. Clin. Biol. Res., Vol. 169, Biological Perspectives on Aggression, pp. 135-179. Eds K. Flannelly, R. Blanchard \& D. Blanchard. A. R. Liss, New York. vom Saal, F.S. (1989) Sexual differentiation in litter bearing mammals: influence of sex of adjacent fetuses in utero. J. Anim. Sci. 77, in press.

vom Saal, F.S. \& Bronson, F.H. (1978) In utero proximity of female mouse fetuses to males: effect on reproductive performance during later life. Biol. Reprod. $19,842-853$.

vom Saal, F.S. \& Bronson, F.H. (1980a) Sexual characteristics of adult female mice are correlated with their blood testosterone levels during prenatal development. Science, N.Y. 208, 597-599.

vom Saal, F.S. \& Bronson, F.H. (1980b) Variation in length of the estrous cycle in mice due to former intrauterine proximity to male fetuses. Biol. Reprod. 22, 777-780. vom Saal, F.S. \& Finch, C.E. (1988) Reproductive senescence: phenomena and mechanisms in mammals and selected vertebrates. In Physiology of Reproduction, pp. 2351-2413. Eds E. Knobil \& J. Neill. Raven Press, New York.

vom Saal, F.S. \& Moyer, C. (1985) Prenatal effects on reproductive capacity during aging in female mice. Biol. Reprod. 32, 1116-1126.

vom Saal, F.S., Pryor, S. \& Bronson, F.H. (1981) Change in oestrous cycle length during adolescence in mice is influenced by prior intrauterine position and housing. J. Reprod. Fert. 62, 33-37.

vem Saal, F.S., Grant, W., McMullen, C. \& Laves, K. (1983) High fetal estrogen titers are correlated with enhanced adult sexual performance and decreased aggression in male mice. Science, N.Y. 220, 1306-1309.

Wechman, R., Brown, M. \& Hilton, F. (1985) Intrauterine position affects sex-accessory biochemistry in adult female mice. Biol. Reprod. 33, 803-807.

Received 24 August 1988 